\title{
Social media as platforms for information sharing among librarians in Anambra State, Nigeria
}

\author{
Ngozi P. Osuchukwu, CLN \\ Department of Library and Information Science \\ Nnamdi Azikiwe University, Awka \\ Anambra State, Nigeria \\ E-mail: ngostray2k@yahoo.com \\ Oluchi Nguzoro, $C L N$ \\ British Spring College, Awka \\ Anambra State, Nigeria \\ E-mail: nguzorooluchi@yahoo.com
}

\begin{abstract}
The global trend on the use of social media has enhanced professional information sharing and networking. This development has created spaces for groups that determine who gets informed, updated, inspired and connected as members. The librarians in Nigeria are not left out in this strategic phenomenon. This paper evaluated the different social media platforms used by librarians in Nigeria, the benefits and the challenges. It was an expository research that employed focus group discussion. A total of 12 librarians from different institutions participated in the discussion. Interview was also used to elicit data. The findings revealed that WhatsApp was rated $100 \%$ as the number one social media platform used by librarians, followed by Facebook with $80 \%$, twitter $50 \%$, Instagram and LinkedIn $41.7 \%$, respectively while Skype rated $33 \%$ and blog $25 \%$. It was also discovered that $50 \%$ of the respondents belonged to 6-10 professional groups while 33\% and 25\% belonged to over 11 professional groups on WhatsApp and Facebook, respectively. Benefits that were derived through the social media platforms are awards, sponsorships, collaboration, updates, networking, supports, exchange of ideas and professional relationship. However, unwanted copy and paste, inactive participation, personal and business advertisements, information explosion and disregards to rules and regulations of the platforms affect their use of the social media groups. It was therefore, recommended that strict sanctions should be placed on unwanted posts as well as punishment on members that err. The implication is that if decorum was not placed on social media platforms, there would be no meaningful sharing of information and full participation of members.
\end{abstract}

Keyword: Social media platforms, Open groups, Information sharing, Librarians, Nigeria

\section{Introduction}

The entire business of libraries is connecting people with information and this is what global trend emphasizes. The emergence of technology makes it easier by developing social media to make the business of information, more convenient and faster with overwhelming tentacles to all parts of the globe. With internet connectivity, networking and sharing become astounding, providing access to information in ways that mix, mash and amaze. Librarians have embraced this technology to navigate their sharing and creation of access to information to individuals and groups through social media. Dunkerley, Allen, Pearman, Karanasios and Crump (2014) pointed out that not only has this changed the way we seek, retrieve, share and use information in everyday life, it has also transformed information practices in organizational settings.Thus, the number of closed groups in social media platforms for information sharing is increasing. The members of the groups use the digital platforms to connect, 
Ngozi P. Osuchukwu and Oluchi Nguzoro : Social media as platforms for information sharing among librarians in Anambra State, Nigeria

create, share content and process knowledge (Lewis, 2010). This has made information dissemination easier within the members as well as enhanced speedy transfer of knowledge.

There are several things social media do to information services and sustainable relationship of librarians as partners in information business. It indulges, includes, engages, informs, inspires and connects. In Nigeria, social media platforms are embraced and utilized maximally by librarians and others in different sectors. Active social media platform users in Nigeria have were over 5million in 2013 (Terragon, 2013). The Nigerian Library Association has different sections and chapters with aims and missions for information sharing. There are also institutions and other groups where librarians belong. These groups have avenues of engagement and information sharing (Igberaese \& Akpojotor, 2014). A majority of librarians in Nigeria have been reported to belong to professional association WhatsApp group, followed by group that serves the entire library, staff union group and group created by colleague (Adomi \& Solomon-Uwakwe, 2019). Twitter, Facebook, Instagram, WhatsApp, Youtube and many more have brought people of like minds together to forge a common ground in information network.

However, social media platforms seem to have created new challenges for librarians in information sharing, meeting of user information needs and expectations. As information sources and delivery channels of information seekers change in tandem with advancement in technology, librarians in the need to move with trend. Researches on social media platforms only discuss topics of use and students' assessment of social media. They have not studied the different closed groups in social media platforms and information sharing. Thus, this study evaluated the social media platforms for strategic information sharing in Nigeria with benefits and challenges for librarians in Nigeria.

\section{Objectives of the study}

The objective of this study was to evaluate the social media platforms for strategic information sharing for librarians in Nigeria. Specifically, this paper set out to:

1. identified the different social media and platforms commonly used by librarians in Nigeria

2. Found out the social media groups librarians belong to

3. Harnessed the benefits of social media groups of librarians

4. Looked at the challenges of social media platforms used by librarians in Nigeria

\section{Research questions}

1. What are the different social media platforms commonly used by librarians in Nigeria

2. What are the social media group librarians belong to

3. Are there benefits of social media groups used by librarians in Nigeria

4. What are the challenges of using social media platforms by librarians in Nigeria

\section{Literature review}

Studies have shown that libraries and librarians support the use of social media for information sharing. For instance reports in Francis and Taylor(2014a) international research revealed that 497 responses, that is over $70 \%$ of librarians now feel that the use of SM is important and most libraries (68\%) were managing between one and four SM accounts. Again, employees are given the opportunity to communicate online via social media, professional networking sites, blogs and personal web sites (NLA, 2010). Librarians use U-Tube for sharing 
Ngozi P. Osuchukwu and Oluchi Nguzoro : Social media as platforms for information sharing among librarians in Anambra State, Nigeria

information, presentations and talks organized on different topics, Facebook, LinkedIn, WhatsApp, blogs, Flickr, YouTube, iTunes and Twitter and skype (Hendrix \& Zafron, 2009; Braziel, 2009 and Ghaisani, Handayani \& Munajat, 2017). Different libraries also use Wikis for content creation and collaborative relation between library and the community. Others are IM (Instant Messaging), SMS, twitter and email are being for answering questions (Olasina, 2013; Rogers, 2012and Convertive, 2011). Statistics of Social media usage shows that there are nearly 700 million active Facebook users, over 100 million LinkedIn members, 5 billion+ images on Flickr, 24 million pages on Wikipedia, 300 million Twitter users posting over 7,000 tweets per second, over 2.9 billion hours of YouTube watching per month (Tortorella, 2012). These statistics include librarians and libraries.

Evidences abound where librarians use different social media for information dissemination. Olajide, Otunya and Omotayo (2017) stated that the use of social media has shown great influence and increased reach, socialization, knowledge, information dissemination. National Library of Australia (NLA, 2010) embraced the use of social media as a corporate communication and community building tools for engagement. Library of Congress used social media for marketing its services and to interact with its online users (Braziel, 2009).Ezeani and Igwesi (2012) informed that these tools are used to be able to keep up with their patrons on real time. Indeed many librarians use social media platforms to market the library and push out announcements to library users for promotional purpose. Based on this, librarians post photos, videos, graphics and audio to provide chat reference services. The impact is the changes in the roles of librarians in the global information trend which has become unique and critical to information availability and distribution.

Today in Nigeria, librarians have different closed groups of social media that one may find himself belonging to over ten groups and counting. These are all effects of strategic sharing to ensure that information business is kept alive with professionals who are ready to take action in sharing. According to Ghaisani, Handayani and Munajat (2017) information is shared within the group of friends and colleagues. Clearly, librarians, institutions and everyone need to become more media savvy (Taylor \& Francis, 2014b and Anyira, 2011). Such information can enhance a discussion on research, knowledge management, conferences, scholarships, funding, recommendation for outing and other social activities. Information sharing in closed groups can become limitless as long as they suit the purposes or rules of the group. What this means is that, there is communityrelated information that brings the members together which usually leads to professional and personal gain (Munar \& Jacobsen 2014).

Experiences have shown that librarians benefit a great deal from social media platforms. Social media has the possibility of building closer relationships between librarians and stakeholders; librarians and patrons; librarians and community dwellers; librarians and duty bearers and other professionals. Social media has contributed in making the voices of libraries and librarians heard and adhered to. Many librarians have gained financially, gotten scholarships, funding opportunities, grants and other freebies through social media platforms. Interestingly, social media platforms have created the opportunity where professionals meet with chances of interactive sessions and feedback which help in reforming service delivery and quality assurance on distribution both in physical 
Ngozi P. Osuchukwu and Oluchi Nguzoro : Social media as platforms for information sharing among librarians in Anambra State, Nigeria

and virtual fields (Waddell \& Barnes, 2012; Bakare \& Umar, 2018; Igun, 2010).

The influx of social media and the seeming compulsory to identify with colleagues from different groups seem to be hinged on challenges for information sharing (Sanusi, Adelabu \& Okunade, 2014).A study by Oyovwe-Tinuoye and Adomi (2019) on use of WhatsApp for the 2019 Nigerian Library Association election exercise revealed that a most of their respondents used NLA State chapter group WhatsApp to campaign for candidates; that WhatsApp platform enabled respondents to receive information about election timetable, arrival of ballot papers, voting, outcome of election, reactions of election outcome and among others; that use of harsh language by some people for campaign, inability to keep track of campaign posts because of the frequency of posts, negative reactions to posts by supporters of some candidates, inability of the administrator to call some offenders to order in group WhatsApp and among others were drawbacks to use of WhatsApp for the election exercise. Librarians in the digital era have enormous responsibilities of consulting wide variety of resources and services that expand beyond the typical eight-hour work day. They have the important roles of controlling the information resources in physical and virtual domains, accessing the internet and the World Wide Web as well as the social media in order not to miss anything. These have led to challenges of information explosion and the inability to cope with overwhelming information generation. But then, the 21st century librarians must re supposed to tackle the expectations of the information society.

\section{Methods}

This was an expository research that adopted focus group discussion (FGD) to investigate the social media platforms used, the challenges and prospects for librarians in Nigeria. The study reviewed the open and closed social media platforms under focus group discussion and interviews. Twelve librarians from Nigerian Library Association, Anambra State Chapter were used for the study. The participants belonged to the same profession and closed group social media platforms, thus, have homogenous tendencies to address the issue. The discussion was planned, fixed by the researchers which yielded results for the study. It was all interactive. The data was collated and analyzed using tables, simple frequencies and narrative styles. 
Ngozi P. Osuchukwu and Oluchi Nguzoro : Social media as platforms for information sharing among librarians in Anambra State, Nigeria

\section{Findings}

Table 1: Demographic characteristics of the respondents

\begin{tabular}{|c|c|c|c|c|}
\hline \multirow{7}{*}{$\begin{array}{l}\mathbf{S} / \mathbf{N} \\
1 .\end{array}$} & Institutions & Number & Percentage & Sex \\
\hline & Academic Library & 6 & 50 & Female \\
\hline & Public Library & 5 & 41.7 & \\
\hline & Research Library & - & & \\
\hline & School Library & 1 & 8.3 & \\
\hline & National Library & - & & \\
\hline & Total & 12 & 100 & \\
\hline \multirow[t]{5}{*}{2.} & $\begin{array}{l}\text { Academic } \\
\text { Qualification }\end{array}$ & & & \\
\hline & Ph.D & 1 & 8.3 & \\
\hline & MLIS & 6 & 50 & \\
\hline & BLIS/HND & 5 & 41.7 & \\
\hline & Total & 12 & 100 & \\
\hline \multirow[t]{6}{*}{3.} & Age range & & & \\
\hline & Below 30 years & 2 & 17 & \\
\hline & $31-40$ & 5 & 41.7 & \\
\hline & $40-50$ & 4 & 33 & \\
\hline & 50 and above & 1 & 8.3 & \\
\hline & Total & 12 & 100 & \\
\hline \multirow[t]{6}{*}{4.} & Work experience & & & \\
\hline & Below 5 years & 4 & 33 & \\
\hline & $6-10$ years & 5 & 41.7 & \\
\hline & $11-15$ years & 2 & 17 & \\
\hline & 16 years and above & 1 & 8.3 & \\
\hline & Total & 12 & 100 & \\
\hline
\end{tabular}

Table 1 shows that the participants were drawn from different libraries in the state. While $50 \%$ were from academic libraries, $33 \%$ were from public library and $7 \%$ from school library. No one came from National and research libraries. It was also shown that one of the participants had PhD while $50 \%$ has MLIS and $41.7 \%$ has BLIS/HND. The participants have working experiences and their ages ranged from below 30years $-17 \%$, $41.7 \%$ within $31-40$, 33\% within $40 \mathrm{~m}-50$ and 1 person above 50 years. This table shows that participants were mixed and drawn from different sectors and different ages to have wide views of input. 
Ngozi P. Osuchukwu and Oluchi Nguzoro : Social media as platforms for information sharing among librarians in Anambra State, Nigeria

Table 2: Ranking of the most common social media platforms used by librarians in Nigeria

\begin{tabular}{lll}
\hline Social media platforms & Rank & Remark \\
\hline WhatsApp & $1^{\text {st }}$ & $100 \%$ are on WhatsApp \\
Facebook & $2^{\text {nd }}$ & $80 \%$ on Facebook \\
Twitter & $3^{\text {rd }}$ & $50 \%$ on Twitter \\
Instagram & $4^{\text {th }}$ & $41.7 \%$ on Instagram \\
LinkedIn & $5^{\text {th }}$ & $41.7 \%$ on Linked in \\
Skype & $6^{\text {th }}$ & $33 \%$ on Skype \\
Blogs & $7^{\text {th }}$ & $25 \%$ \\
\hline
\end{tabular}

The findings revealed that WhatsApp was rated $100 \%$ as the first social media platform used by librarians, followed by Facebook with $80 \%$ as the second, while Twitter was third $50 \%$, Instagram $4^{\text {th }}$ and LinkedIn rated
$41.7 \%$, respectively. Skype rated $33 \%$ and blog $25 \%$. The participants further stated that WhatsApp was the most convenient and fastest of sharing information as long as one has internet connectivity.

Table 3: Professional social media group belonged to

Social media Number of professional groups belonged to platforms

WhatsApp

\begin{tabular}{llll}
\hline Below & 5 & $\%$ & $\begin{array}{l}\text { From } \\
\text { groups }\end{array}$ \\
groups & &
\end{tabular}

Facebook

$\begin{array}{lll}2 & 17 & 6 \\ 3 & 25 & 6\end{array}$

6-10 \%

\begin{tabular}{lllll}
$\%$ & $\begin{array}{l}11 \text { groups } \\
\text { above }\end{array}$ & and & $\%$ & Total \\
50 & 4 & 33 & 100 \\
50 & 3 & 25 & 100 \\
\hline
\end{tabular}

Table 3 shows the most popular social media groups librarians belonged to. $17 \%$ of the participants belonged to less than 5groups in WhatsApp and Facebook. 50\% of the respondents belonged to 6-10groups. While $33 \%$ and $25 \%$ belonged to over 11 professional groups in WhatsApp and Facebook, respectively.

Going further, all the participants stated that they found themselves in some groups without even applying to join. They revealed that their colleagues added them without their permission, although, some of them are compulsory being official groups in their institutions. This shows that librarians have many groups in social media that requires members' participation in Nigeria.

Table 4: Benefits obtained from the social media group platforms

\begin{tabular}{llll}
\hline S/N & Items & Number & \% \\
\hline 1. & Award & 3 & 25 \\
2. & Sponsorship & 3 & 25 \\
3. & Grant & 3 & 25 \\
4. & Collaboration/partnership/networking & 8 & 66 \\
5. & Employment spaces & 4 & 33 \\
6. & Supports/volunteer & 6 & 50 \\
7. & Group writing and publication & 6 & 50 \\
8. & Ideas/knowledge/sharing & 12 & 100 \\
9. & Minimized travelling for meetings & 12 & 100 \\
\hline
\end{tabular}


Ngozi P. Osuchukwu and Oluchi Nguzoro : Social media as platforms for information sharing among librarians in Anambra State, Nigeria

Table shows that $25 \%$ of the participants have won awards, sponsorships and grants through information shared on their professional groups, while $66 \%$ has enjoyed good collaborations, networking and partnership through group recommendations and information sharing. Again $60 \%$ has received volunteers and supports for programs as well as co-authorship and publication. $33 \%$ has gained employment and $100 \%$ benefitted from exchange of ideas, knowledge and sharing as well minimized travelling for meetings.

Table 5: Challenges of social media platforms used

\begin{tabular}{llll}
\hline S/N & Items & Number & \% \\
\hline 1. & Unwanted copy and paste & 12 & 100 \\
2. & Disregard to rules and regulations of the group & 12 & 100 \\
3. & Information explosion & 10 & 83 \\
4. & Inactive participation of some members during online meeting & 8 & 66 \\
5. & Unsavory comments that cause friction in the group & 8 & 66 \\
6. & Inability of the admin to delist offending members from the group & 12 & 100 \\
7. & Delay and dragging of important issues in the platforms & 10 & 83 \\
8. & Verbal attacks and open quarrel & 6 & 50 \\
9. & Business and personal advertisement & 6 & 50 \\
10 & Hacking into the group & 8 & 66 \\
\hline
\end{tabular}

The Table 5 shows that unwanted copy and paste, disregard to rules and regulations of the group and inability of the admin to delist offending members from the group posed as the greatest challenges of the social media groups with $100 \%$ rate. Others were delay and dragging of important issues in the platforms and information explosion at $83 \%$, respectively, inactive participation of some members during online meeting, unsavory comments that cause friction in the group and hacking into the group at $66 \%$. This was followed by verbal attacks and open quarrel together with business and personal advertisement at $50 \%$.

\section{Discussion}

The study has shown that librarians in Nigeria use social media in information sharing and other activities. Librarians from different types of libraries were represented in the discussion, depicting age ranges, working experiences and qualifications. The indication is that social media platform is embraced by all to show compliance in the information era where every professional is attuned to global trend.

Results showing the most popular social media platforms (Table 2) used as WhatsApp and Facebook, followed by twitter and others revealed what works for librarians in Nigeria. It also corresponds with Tortorella (2012) assertion that over 700 million people use Facebook which is the most common social media platform in the world. It becomes clear that WhatsApp and Facebook top the list of online chart for information sharing in Nigeria.

Obviously, that must have made WhatsApp and Facebook to have the largest closed group members (Table 3). It is therefore not surprising that the participants of this study belonged to many professional closed groups at the same time as friends and colleagues, navigating for information sharing and knowledge impact which was also highlighted by Ghaisani, Handayani and Munajat (2017).

Undoubtedly, social media platforms with closed groups have lots of benefits. 
Ngozi P. Osuchukwu and Oluchi Nguzoro : Social media as platforms for information sharing among librarians in Anambra State, Nigeria

With participants winning grants, sponsorship and scholarships from the information shared on the social media platform shows the values they add for forming the mutual group. The disclosure that they enhanced collaboration, writing groups, publication, exchange of ideas and notification of meetings and conferences make them good practices that should be upheld for all time opportunities platforms.

However, the challenges revealed the attitudes of some members of the groups who do not conform to the rules and regulations of the closed group, thereby causing unwanted rancor and friction. Thus, the posting of unnecessary copy and paste, refusal to appear or make input or participate during online meetings and unsavory comments among others can destroy a group. The indication is that such approaches may cause friction in the group which will inherently affect smooth sharing and networking.

\section{Implication of the findings}

The study has revealed that social media platforms are popular with Nigerian librarians, many of whom belong to closed groups that disseminate valuable information for growth and development. It has also shown that the regulations of the online groups are sometimes floated by professionals. This is absurd. The implication is that if decorum was not applied in professional groups and sanctions are not placed on offenders, there may not be meaningful sharing of information. The aim for the group will not be achieved and professional development may be hampered. Therefore, the values which the closed group of social media platforms are createdmust be sustained for the best practices to thrive.

\section{Conclusion}

It has become clear the essence of social media platforms with closed group and active participation of members. The $21^{\text {st }}$ century information society with professionals in the information business must remain relevant for inclusive knowledge economy. Every library sector is important, just like every librarian has something to offer in the social media platform. Thus, this study concludes that:

1. Librarians must endeavor to assess other social media platforms other than whatsapp and facebook for more information retrieval

2. Active participation is a necessity for members of any closed group for that is the avenue to participate and contribute in updates

3. The benefits are enormous and should be encouraged as well as motivate everyone to gain from them

4. The closed group must not be allowed to extinct because of few members' attitudes. Warnings should be sent to violators of groups' regulations while punitive measures can be given to maintain the dignity of the group media.

Based on the study, it was recommended that:

1. Librarians should be encouraged to assess more social media platforms for more benefits, information generation, networking and sharing.

2. There should be regular updates on the rules and regulations of professional social media closed group platform to remind members of the focus of the group.

3. Strict sanctions should be placed on unwanted posts as well as punishment on members that err. 
Ngozi P. Osuchukwu and Oluchi Nguzoro : Social media as platforms for information sharing among librarians in Anambra State, Nigeria

\section{References}

Adomi, E. E. \& Solomon-Uwakwe, B. (2019). Work related WhatsApp groups as knowledge sharing platforms among librarians in selected federal universities in Nigeria. Journal of ICT Development, Applications and Research, 1, 11 - 19. Retrieved from http://www.credencepressitd.com/jou rnal/uploads/archive/2019156438727 56431755827.pdf.

Anyira, I. E. (2011). Internet services in Nigerian private Universities: A case study. Retrieved from https://digitalcommons.unl.edu/cgi/vi ewcontent.cgi article $=1565 \&$ context $=$ libphilprac.

Bakare, O. A. \& Umar, M Y. (2018). Use of social media platforms to promote library services and profitable librarianship. International Journal of Science and Engineering Research, 9(7), 324-334

Braziel, L. (2009). Social media marketing example \#12: Library of Congress. Retrieved from http://www.igniteso cialmedia.com/social-mediaexamples/social-media-marketingexample-library-of-congress/.

Convertive (2011). Using social media in . major library systems. Retrieved from http://www.convertiv.com/usin g-social-media-in-a-major-librarysystem/.

Dunkerley, E., Allen, D., Pearman, A., Karanasios, S. \& Crump, J. (2014).The influence of social media on information sharing and decision making in policing: research in progress. Information Research, 19 (4), 1-8.

Ezeani.C. N. \& Iqwesi, U. (2012). Using social media for dynamic library service delivery: The Nigerian experience. Retrieved from http://digitalcommons.unl.edu/libphil prac/814

Ghaisani, A. P., Handayani, P. W. \&

Munajat, O. (2017). Users' motivation in sharing information on social media. Procedia Computer 124 (2017), 530-535.

Hendrix, D. \& Zafron, M. L. (2009). Use of Facebook in academic health sciences libraries. Journal of Medical Library Association, 97(1), 44-47.

Igberaese, M. O. \& Akpojotor, O. L.(2014). Use of social media for information sharing among students of Federal University of Petroleum Resources Effurun. Journal of Applied Information Science and Technology, 7 (2), 38-45.

Igun, S.E. (2010). Gender and librarians' information and communication technology (ICT) utilization access points in Nigerian University Libraries. Delta Library Journal, $4(1 \& 2), 18-21$.

Lewis B. (2010). Social media and strategic communication: Attitudes and perceptions among college students. Public Relations Journal, 4 (3).

Munar, A. \& Jacobsen J. (2015). Motivations for sharing tourism experiences through social media. Tourism Management. 43, 46-54.

NLA (2010). National Library of Australia publishes social media guidelines. Retrieved from http://web.resource shelf.com/go/resourceblog/62891.

Olajide, A. F., Otunya, A. O. \& Omotayo, O. A. (2017). How libraries are using social media: Nigeria perspective. International Journal of Digital Library Services, 7 (3): 79-94.

Olasina, G. (2011). The use of web 2.0 tools and social networking sites by librarians, information professionals and other professionals in 
Ngozi P. Osuchukwu and Oluchi Nguzoro : Social media as platforms for information sharing among librarians in Anambra State, Nigeria

workplaces in Nigeria. Pacific Northwest Library Association, PNLA Quarterly, PNLA Quarterly 75 (3):11-43. (Spring)

Oyovwe-Tinuoye, G. O. \& Adomi, E. E. (2019). WhatsApp and the 2019 Nigerian Library Association (NLA) election exercise.Journal of Library Services and Technologies, 1(2), 14 -31. Retrieved from www.creden cepressitd.com/journal/uploads/archive/ 202015805126355230556880.pdf.

Sanusi, B. C, Adelabu, O. \& Okunade, J. K. (2014). Adapting social media for formal learning in Nigeria: challenges and prospects. Arabian Journal of Business and Management Review, (OMAN Chapter) 3(9).

Taylor \& Francis (2014a). What is the future of social media in the library? A white paper from Taylor and Francis. Retrieved from www.tandf.co.uk/ journals/access/white-paper-infogra phic-social-media-future.pdf.
Taylor \& Francis (2014b). Use of social media by the libraries: Current practices and future opportunities. A White paper from Taylor and Francis. Retrieved from www.tandf .co.uk/journals/access/white-paperssocial-media.pdf.

Terragon Limited. (2013). State of digital media in Nigeria. Retrieved from http://slideshares.net/mobile.

Tortorella, D. (2012). Library marketing and promotion via social media. Retrieved from http://infopeople.org /training/library-marketing-andpromotion-social-media.

Waddell, D. C. \& Barnes, M. \& KhanKernaham (2012). Tapping into the power of twitter: Look at its potential in Canadian health library. Partnership: The Canadian Journal of library and Information Practice and Research, 7 (2). 